\title{
Xylogenesis of Pinus pinaster under a Mediterranean climate
}

\author{
Joana Vieira $\cdot$ Sergio Rossi $\cdot$ Filipe Campelo • \\ Helena Freitas • Cristina Nabais
}

Received: 17 May 2013 / Accepted: 4 October 2013

(C) INRA and Springer-Verlag France 2013

\begin{abstract}
- Context The knowledge on cambial activity in water-limited environments, such as the Mediterranean, is still fragmentary. Dendrochronological studies have determined that spring precipitation plays an important part in determining tree-ring width and the properties of tracheids. However, the complex relation between cambial phenology and climate is still far from understood.

- Aims We studied the influence of climate, especially water stress, on maritime pine wood formation with the aim of determining the influence of drought on cambial activity.

- Methods A plantation of maritime pine (Pinus pinaster) was selected in the west coast of Portugal, to monitor cambial activity and wood formation using anatomical observations and band dendrometers. The trees were monitored weekly over 2 years (2010 and 2011).

- Results Xylem differentiation started earlier when warmer late winter temperatures were observed. Water stress triggered an earlier stop of wood formation and also the formation of tracheids with smaller lumen area. In both years a bimodal pattern of stem radial increment was registered by band dendrometers with two periods of increment: one in spring and another in autumn. The xylem anatomy study suggests that the autumnal increment period corresponded mostly to stem rehydration, since the differentiation of new xylem cells by the cambium was not observed.
\end{abstract}

\section{Handling Editor: Gilbert Aussenac}

J. Vieira $(\triangle) \cdot$ F. Campelo $\cdot$ H. Freitas $\cdot$ C. Nabais

CFE - Centro de Ecologia Funcional, Departamento de Ciências da

Vida, Faculdade de Ciências e Tecnologia, Universidade de Coimbra,

Apartado 3046, 3001-401 Coimbra, Portugal

e-mail: joana.vieira@uc.pt

S. Rossi

Départment des Sciences Foundamentales, Université du Québec à

Chicoutimi, Chicoutimi, Canada
- Conclusion Maritime pine cambial activity appears to be under a double climatic control: temperature influences cambial onset and water availability growth cessation.

Keywords Wood formation · Drought · Mediterranean · Maritime pine $\cdot$ Dendrometers

\section{Introduction}

Environmental factors affect wood formation at different levels, from a slight variation in lumen area to the complete absence of a tree ring (Fritts 1976). In general, low temperature is the main limiting factor of radial growth in trees of high latitudes and altitudes (Rossi et al. 2007), whereas temperate species are controlled by a combination of temperature and water availability (Carrer and Urbinati 2006). In dryer areas such as the Mediterranean region, however, tree growth is mainly limited by water availability (Cherubini et al. 2003). Several dendrochronological studies carried out in this region have demonstrated the importance of water availability, especially during spring, on tree growth. A positive relation between earlywood widths and May precipitation was observed in maritime (Pinus pinaster Ait.) and Aleppo pines (Pinus halepensis L.), two typical Mediterranean species (Campelo et al. 2013; Vieira et al. 2010; de Luis et al. 2009). A broader study by Lebourgeois et al. (2012) showed that spring drought (May-June) was the primary factor limiting conifer growth in the Mediterranean, with narrower tree rings being observed in years with a drier spring.

Although a strong relation between tree-ring width and climate has been established in the Mediterranean area, all of the abovementioned studies were performed retrospectively, using correlations between tree-ring width series and monthly climatic variables, without considering wood formation at the intra-annual scale. Studies on the wood formation of Spanish 
juniper (Juniperus thurifera L.) and Aleppo pine have described xylem production to occur in two different seasonal periods: spring and fall (Camarero et al. 2010; de Luis et al. 2007). This growth pattern has been described as the bimodal growth pattern and is characteristic of water-limited environments, such as the Mediterranean (Liphschitz and Levyadun 1986; Camarero et al. 2010). Apart from the seasonal pattern of xylem growth, Camarero et al. (2010) also observed that onset and duration of xylogenesis were mainly determined by temperature and that a longer duration of xylogenesis resulted in the formation of more tracheids.

Even though there are some studies on the cambial activity of trees from water-limited environments (Camarero et al. 2010; de Luis et al. 2007; Linares et al. 2009), the established knowledge is still fragmentary, especially in terms of the climatic influence on xylogenesis. Xylem anatomical features are the result of a compromise between conductivity efficiency and safety (Sperry 2003; Tyree and Zimmermann 2002). Lumen diameter is thus the result of a trade-off between increasing efficiency and decreasing safety in water conductivity (Hacke and Sperry 2001; Tyree and Zimmermann 2002). In the Mediterranean area Pasho et al. (2012) observed that Aleppo pine trees presented a bigger proportion of latewood tracheids in response to decreased precipitation and high temperatures. In a dry inner Alpine valley, however, an irrigation experiment revealed that nonirrigated trees presented tracheids with a wider lumen than control trees (Eilmann et al. 2011). The xylem anatomy response appears to change considerably between environments and/or species. The climate is changing, and the frequency of extreme warm years in Europe is expected to increase (IPCC 2007). Understanding how cambial activity and wood structures are affected by warm and dry periods is crucial to predict how forest productivity will respond to the predicted climatic changes. Ecosystems such as Mediterranean forests are excellent locations to analyze the effect of drought on wood formation. In the present study, we monitored wood formation in 2 years, 2010 and 2011, in order to determine the influence of drought on tree growth. We have tested the hypotheses that (1) timings of wood formation and (2) the anatomy of tracheids are affected by drought.

\section{Material and methods}

\subsection{Study site and climatic data}

The study was conducted in Perimetro Florestal Dunas de Cantanhede $\left(40^{\circ} 21^{\prime} 35.15^{\prime \prime} \mathrm{N}, 8^{\circ} 49^{\prime} 10.06^{\prime \prime} \mathrm{W} ; 15 \mathrm{~m}\right.$ a.s.1.) on the west coast of Portugal. The study site is a plantation of maritime pine (P. pinaster Ait.) on sand dunes. The soil type is podzol, developed from sand and sandstone. It has a coarse granulometry and sandy texture in all horizons, which gives it a low water-holding capacity (Ferreira et al. 2010). The study site is characterized by dominant and codominant trees with an average age of 45 years and a density of c.a. 230 trees ha ${ }^{-1}$. The trees presented a diameter at breast height (DBH) of $24.8 \pm$ $4.6 \mathrm{~cm}$ and height of $15.4 \pm 0.7 \mathrm{~m}$. Thirty-three dominant trees were selected for the present study, 25 for the diameter increment monitoring and eight for the anatomy study. The same trees were monitored in the two study years. The climate is typically Mediterranean with a strong oceanic influence. Precipitation occurs mainly in autumn and winter and the summer is hot and dry (Fig. 1(a)). The monthly meteorological data (maximum and minimum temperature and total precipitation), was downloaded from the closest grid point to the study site in CRU (8.75 E; $40.25 \mathrm{~N}$; approximately $13 \mathrm{~km}$ from the study site), for the period 1950-2011.

The standardized precipitation-evapotranspiration index (SPEI) was calculated to evaluate the joint effect of temperature and precipitation, by calculating the monthly difference between precipitation and potential evapotranspiration for the 1950-2011 period (Vicente-Serrano et al. 2010). The SPEI includes a climatic water balance which allows to calculate the water deficits and surplus at different time scales, it combines the sensitivity of the Palmer Drought Severity Index with changes in evapotranspiration demands, caused by temperature fluctuations and trends (Vicente-Serrano et al. 2010). The SPEI was calculated using the SPEI package from the R freeware program (http://cran.r-project.org). The SPEI is a standardized index with an average of 0 and a standard deviation of 1 , and it can be compared with other SPEI values over time and space. The 2010 and 2011 SPEIs were compared at the scale of 1 month with the SPEI from 1950-2011 by calculating the difference between them in order to identify periods of drought. A period of drought was characterized by a negative SPEI value (Vicente-Serrano et al. 2010).

\subsection{Xylem formation}

Wood samples were collected weekly from March to December 2010 [day of the year (DOY) 62-349] and from March 2011 to February 2012 (DOY 62-409), using a Trephor (Rossi et al. 2006a). The microcores were collected from $45 \mathrm{~cm}$ below and above breast height, on the southfacing side of the tree stem. Sampling was performed in a spiral pattern in order to prevent taking microcores on top of each other. Before sampling, bark was removed in order to reach the living tissues. Between two consecutive sampling dates, microcores were collected at least $5 \mathrm{~cm}$ apart to prevent getting resin ducts from adjacent sampling points. The microcores were placed in eppendorfs filled with alcohol ( $50 \%$ in water) and stored at $5{ }^{\circ} \mathrm{C}$ to avoid tissue deterioration. In the laboratory, the microcores were dehydrated through successive immersions in alcohol and D-limonene and embedded in paraffin (Rossi et al. 2006a). Transverse sections 
Fig. 1 Temperature and precipitation from the nearest grid point (downloaded from the Royal Netherlands

Meteorological Institute). (a)

Mean monthly temperatures recorded in 2010 and 2011 and mean air temperature of historical series recorded from 1950 to 2011. (b) Sum of monthly precipitation recorded in 2010 (black bars) and 2011 (gray bars) and mean precipitation of historical series recorded from 1950 to 2011 (gray line). (c) Standardized precipitationevapotranspiration index [SPEI in 2010 (black circles) and 2011 (gray circles)]. The zero represents the index calculated for the long-term mean (1950-2011), the negative values are drought periods

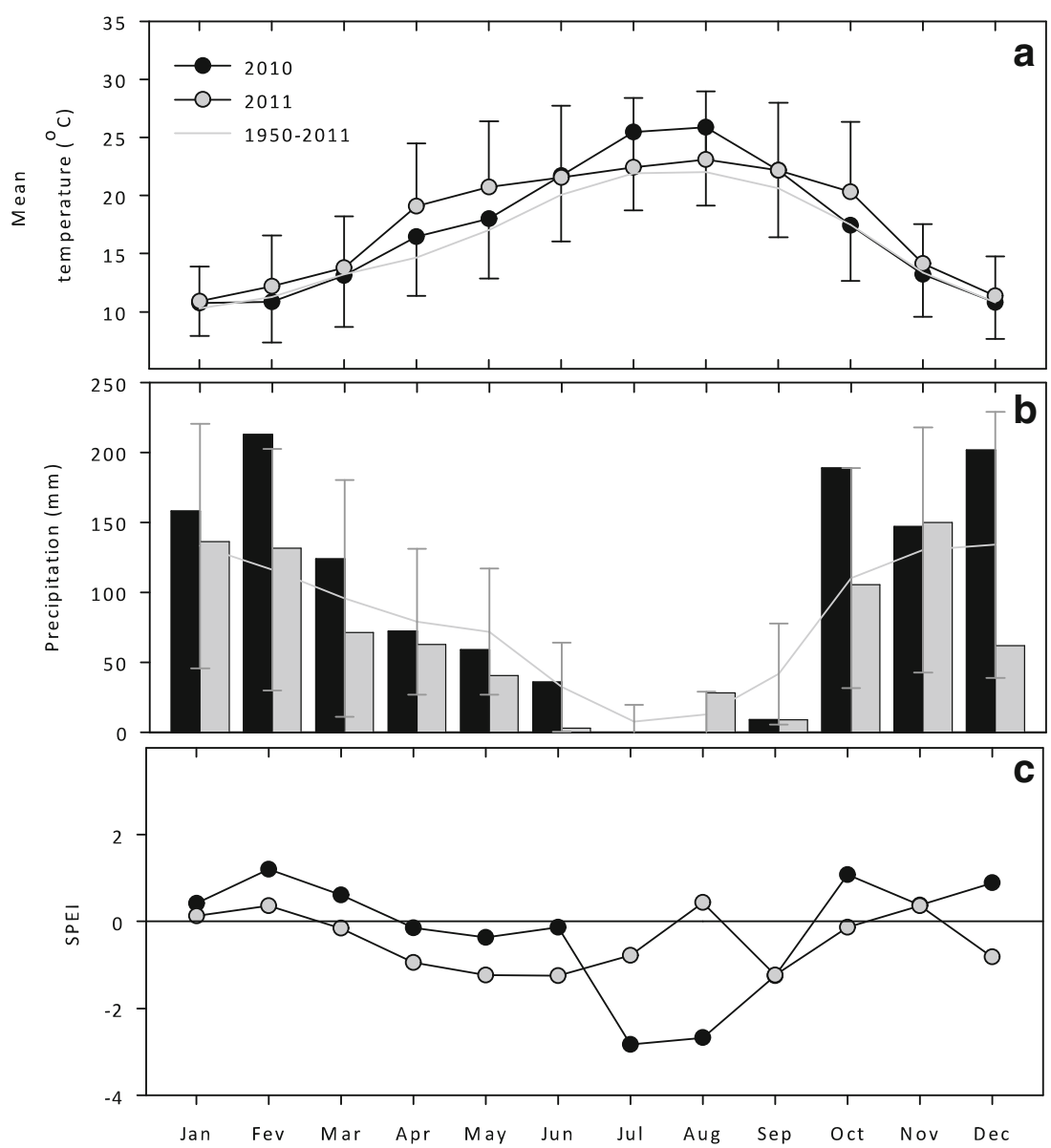

$6-10-\mu \mathrm{m}$ thick were cut from the samples with a rotary microtome, stained with cresyl violet acetate $(0.15 \%$ in water), and immediately observed with a microscope (400$500 \times$ magnification), under visible and polarized light to distinguish the developing xylem cells. Cambial cells are characterized by thin cell walls and small radial diameters, while enlarging cells have a diameter at least twice that of a cambial cell. Wall thickening cells shine under polarized light and show a light violet coloration changing to dark violet at the end of maturation. When the entire cell wall presents a blue coloration, lignification is complete and tracheids reach maturation (Gricar et al. 2005). For each tree, the number of cambial and developing cells was counted along three radial rows and averaged. In the end of the study, the average number of cambial, enlargement, cell wall thickening, and mature cells was determined per sampling date per year.

\subsection{Xylem phenology}

For each tree, the phenology of xylem development in 2010 and 2011 was compared. Two phenophases were considered: cell enlargement and cell wall thickening. The beginning of enlargement, which corresponded to the beginning of wood formation, was considered when more than $50 \%$ of the observed trees presented at least one enlarging cell. The enlargement phase was considered to have ended when more than $50 \%$ of the trees showed no cells in that phase. The same criteria were used to define the beginning and end of the cell wall deposition phase. The onset and end of enlargement and cell wall thickening were determined for each tree. The dates of onset and end of the phenophases were ordered chronologically and fitted to a normal distribution. A normal probability plot was then used to compare the ordered date values with the percentiles of a normal distribution which allowed determining the percentage of trees in each xylem developing stage at any given date. All analyses were performed using SAS 9.2 (SAS Institute Inc., Cary, North Carolina).

\subsection{Cell measurements}

When xylem formation was complete in winter 2012, a microcore was collected per tree on the south-facing side of the stem. The microcores were then embedded in paraffin and cut as described above. The resulting sections were stained with $1 \%$ aqueous safranin and permanently fixed with 
Canada balsam (Eukitt) to measure cell features using Wincell (Regent Instruments Inc.). A camera fixed on an optical microscope was used for image analysis, at $20 \times$ magnification. On each section, three radial paths were selected to measure lumen area and cell wall thickness, along the 2010 and 2011 tree rings. Tracheids were classified in earlywood and latewood following the Mork's formula described in Denne (1989). The measures were averaged by year and the years were compared using a paired $t$ test.

\subsection{Band dendrometers}

To estimate the changes in stem diameter, band dendrometers made of astralon (model D1-L, UMS, Munich, Germany) were installed on 25 trees at breast height. This was done in January 2010 to allow for a period of adjustment before the beginning of the growing season (Linares et al. 2010). Before the installation of dendrometers, the bark was carefully removed with a chisel to better adjust the band dendrometer to the stem and to reduce non-xylematic sources of swelling and shrinking as much as possible (Zweifel et al. 2006). Band dendrometers were read weekly to the nearest $0.01 \mathrm{~mm}$. To avoid biases due to the circadian rhythms of water storage and depletion, all measurements were done in early morning (Linares et al. 2009). Cumulative and weekly dendrometer data were averaged per year.

\section{Results}

\subsection{0 and 2011 climate}

In 2010 and 2011, the mean annual temperature was 1.1 and $1.6{ }^{\circ} \mathrm{C}$ higher than the long-term mean $\left(16^{\circ} \mathrm{C} ; 1950-2011\right)$. The increase in temperature was observed in all months with the exception of January and December, when they were similar to the long-term mean (Fig. 1(a)). The main differences between the 2 years were observed in April, May, July, August, and October. April, May, and October were 2.6, 2.7, and $2.9^{\circ} \mathrm{C}$ warmer in 2011 than in 2010 , whereas July and August where 3 and $2.8{ }^{\circ} \mathrm{C}$ warmer in 2010. The long-term annual precipitation for the area was $965 \mathrm{~mm}$. Total annual precipitation registered in 2010 and 2011 was 1,200 and $800 \mathrm{~mm}$, respectively. The higher precipitation recorded in 2010 was caused by an increase of January, February, March, October, and December precipitation (Fig. 1(b)). The precipitation in 2011 was similar to the long-term mean except for the months of May, June, September, and December, when it was lower. Both studied years showed periods of drought as confirmed by the negative SPEI values (Fig. 1(c)). In 2010, the drought period lasted from April to September, with prominent negative values in July and August, whereas in 2011, the drought period lasted from March to October. Although the SPEI for July was less negative (and even positive in August), spring and early summer were much drier in 2011 than in 2010.

\subsection{Xylem phenology}

In both years, the cambium appeared to be already active on the first sampling date, since it presented a higher number of cells than those observed during winter (Fig. 2). However, cambium phenology presented differences between both years. In 2010, an increase in the number of cambial cells was observed around May (DOY 150), whereas in 2011, the number of cambial cells started to decrease in that period. The maximum number of cambial cells was observed during May-June in 2010 (10 \pm 2 cells), and in March-April during 2011 ( $9 \pm 1$ cell). At the end of summer (September), the number of cells in the cambial zone decreased in both years; however, it was lower in 2011.

Enlargement phase started and ended earlier in 2011. In 2010, the maximum number of enlarging cells was observed in mid-May (DOY 170), whereas in 2011, the maximum number of enlarging cells was observed earlier, in March (DOY 96). In September 2011, there were no longer cells in the enlargement phase, whereas in 2010, enlarging cells were observed until October. Cell wall thickening began earlier in 2011; however, the number of cells observed in 2011 was always inferior to the one observed in 2010 (Fig. 2). The end of this phase was only observed in 2011, in November (DOY 348 ), while in 2010 , there were still tracheids in the cell wall thickening phase at the end of the sampling season (DOY 345). The first mature tracheids were observed in June (DOY $124)$ in both years. However, more tracheids were produced in 2010 than in 2011 (Fig. 2). In the end of 2010, there were 40 mature xylem cells, whereas there were 25 in 2011.

According to the normal distribution the variation in the onset of cell enlargement was higher in 2011, with trees starting enlargement between DOY 68 and 117 (Fig. 3). In 2010, $50 \%$ of the studied trees had begun enlargement in DOY 85 , whereas the same observation was made earlier in 2011, in DOY 75 . Enlargement also ended earlier in 2011; $50 \%$ of the trees had completed it in DOY 254, whereas that was observed in DOY 288 in 2010. Cells were observed in the enlargement phase between February and October in 2010 and February and September in 2011, with a total duration of 203 and 179 days in 2010 and 2011, respectively. Cell wall thickening began earlier in 2011 with half of the trees presenting tracheids in the cell wall thickening phase in DOY 90, compared with DOY 102 in 2010 (Fig. 3). According to the normal distribution, $50 \%$ of the trees ended cell wall thickening on DOY 355 in 2011. On average, in the year 2011, trees presented tracheids in cell wall thickening phase for 265 days, between mid-February and November. The end of cell wall thickening phase was not observed in 2010.

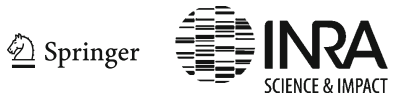


Fig. 2 Number of cambium, enlargement, cell wall deposition, and mature cells of $P$. pinaster during 2010 and 2011. Vertical bars represent standard deviation

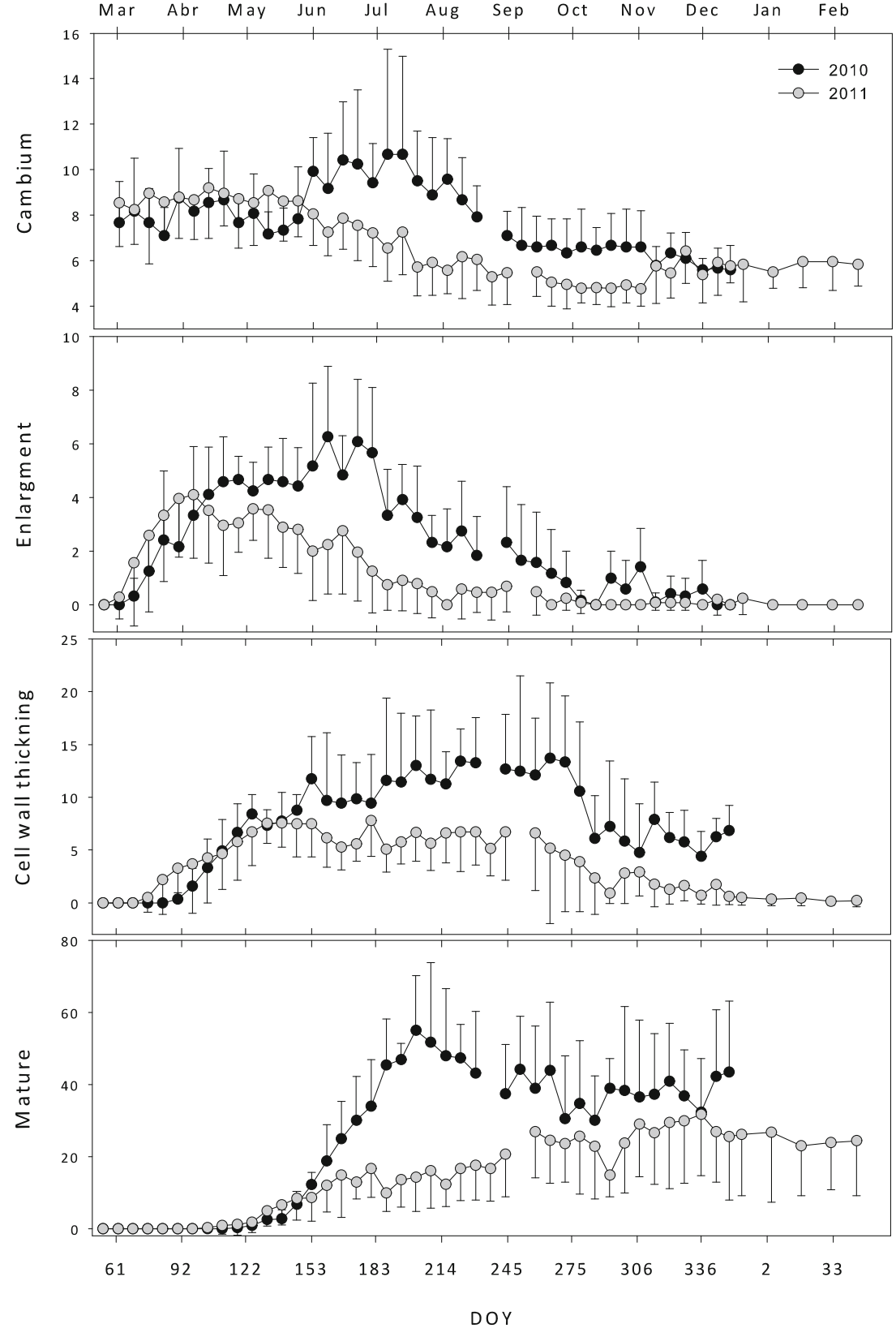

\subsection{Xylem characteristics}

Tracheids characteristics were analyzed in earlywood and latewood and compared between both years. Earlywood cell production and cell characteristics were similar in both years with no significant differences in the studied variables (number of tracheids $t=0.89, p=0.42$; lumen area $t=-0.37$, $p=0.72$, and cell wall thickness $t=2.24, p=0.06$ ) (Fig. 4). Latewood presented a higher number of tracheids in 2010 $(t=3.58, p=0.012)$ with a larger lumen area $(t=2.41$, $p=0.05)$ but a similar cell wall thickness $(t=0.05, p=0.96)$. The number of earlywood cells varied between 12 and 14 , whereas latewood presented an average of 16 and 13 cells in 2010 and 2011, respectively.

\subsection{Stem radius variations}

In both years, stem diameter increments showed a clear bimodal pattern, characterized by a pronounced first period of increment in spring, followed by plateau in summer, and a second less marked period of increment in autumn (Fig. 5). Stem diameter increments showed a high synchrony in the 2-year period, with the same onset date around DOY 75. The maximum increment was reached at the end of April (DOY 112) in 2010 and 10 days earlier in 2011 (Fig. 5(b)). After the maximum, the increment started to decrease, reaching a variation close to zero in August-September (DOY 180-250). The second increment peak was observed in October- 
Fig. 3 Distribution of the onset of cell enlargement (open circle), end of enlargement (open triangle), start of cell wall thickening (closed square) and cessation of wall thickening (closed diamond) for 8 trees of $P$. pinaster in 2010 and 2011 expressed in days of year (DOY)
Year 2010

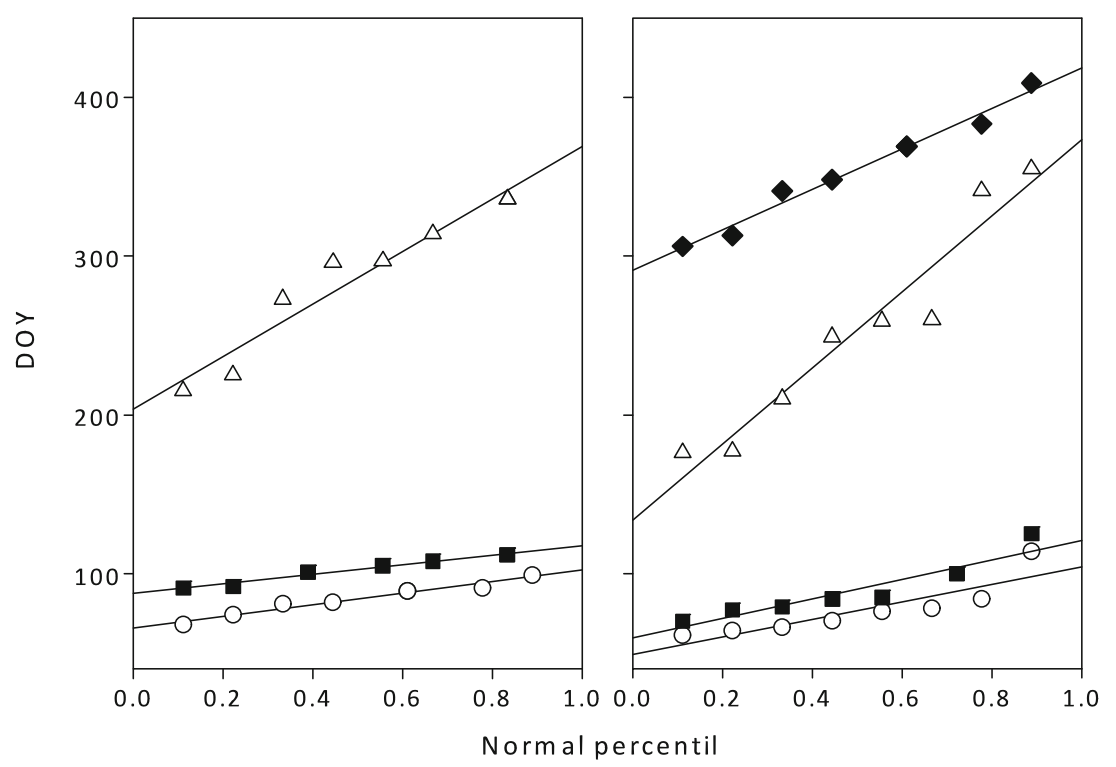

December (DOY 250-340), starting earlier in 2010 (DOY 286) than in 2011 (DOY 306). The total cumulative increment observed in 2010 was higher than in 2011 (Fig. 5(a)).

\section{Discussion}

This study investigated timings and duration of cambium phenology and dynamics of xylem growth in maritime pine in 2 years, 2010 and 2011. The earlier onset of cambial activity in the year with a warmer late winter (2011) suggests that cambial onset in the Mediterranean region is triggered by temperature. We also observed that a pronounced summer drought triggered an earlier stop of cambial activity and that water stress was responsible for the formation of tracheids with a narrower lumen area, confirming our hypothesis that tracheids features are affected by drought. Our findings suggest that in the Mediterranean region, xylogenesis is under a double climatic control: temperature limits growth onset and water availability growth stop.

\subsection{Cambial onset}

A clear relation between temperature and cambial activity has been established in different environments (Rossi et al. 2008; Deslauriers et al. 2008; Begum et al. 2008). Several studies have showed an earlier onset of cambial activity in response to warmer climatic conditions (Korner 1998; Rossi et al. 2008; Deslauriers and Morin 2005) or stem localized heating (Gricar et al. 2006; Oribe et al. 2001; Begum et al. 2007). The earlier onset of cambial activity (enlargement) observed in 2011 could be a response to the warmer late winter, suggesting that
Fig. 4 Early- and latewood number of cells, cell area (micrometers) and cell wall thickness (square micrometers) in 2010 (black circles) and 2011 (gray circles). Vertical bars represent the standard deviation

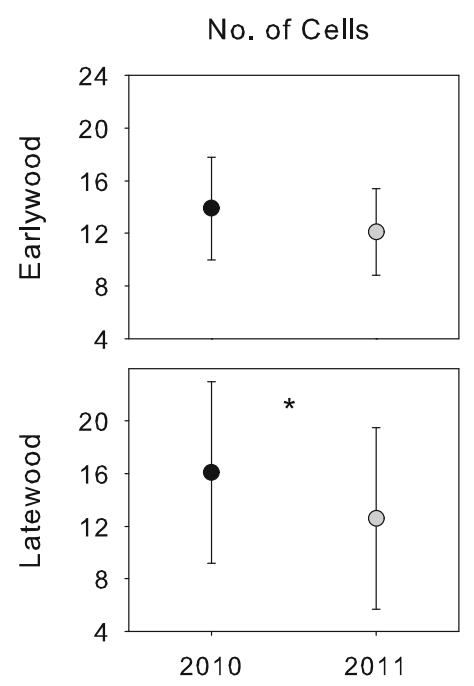

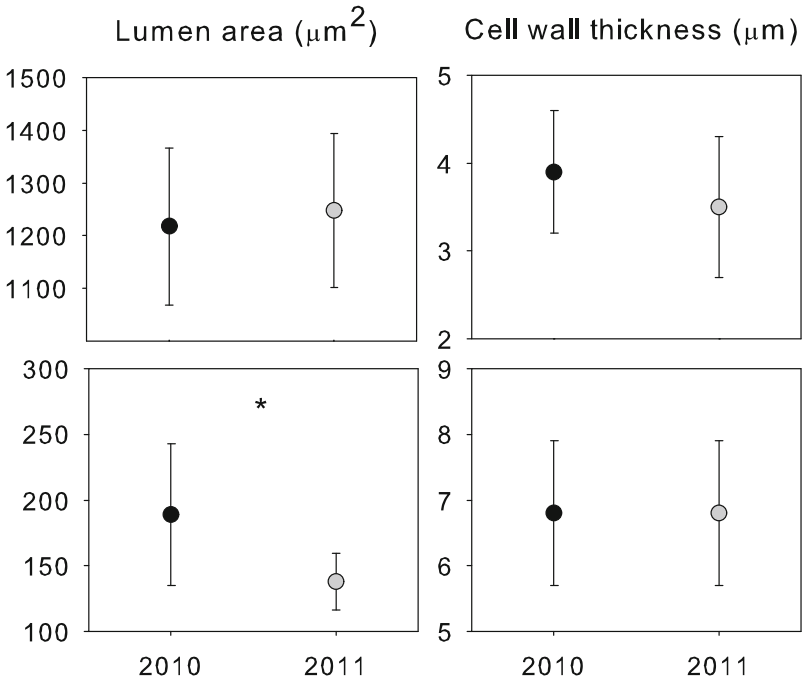


Fig. 5 Cumulative $(a)$ and weekly increments $(b)$ in the stem diameter measured with band dendrometers in 2010 (black line) and 2011 (gray line). Vertical bars represent the standard deviation

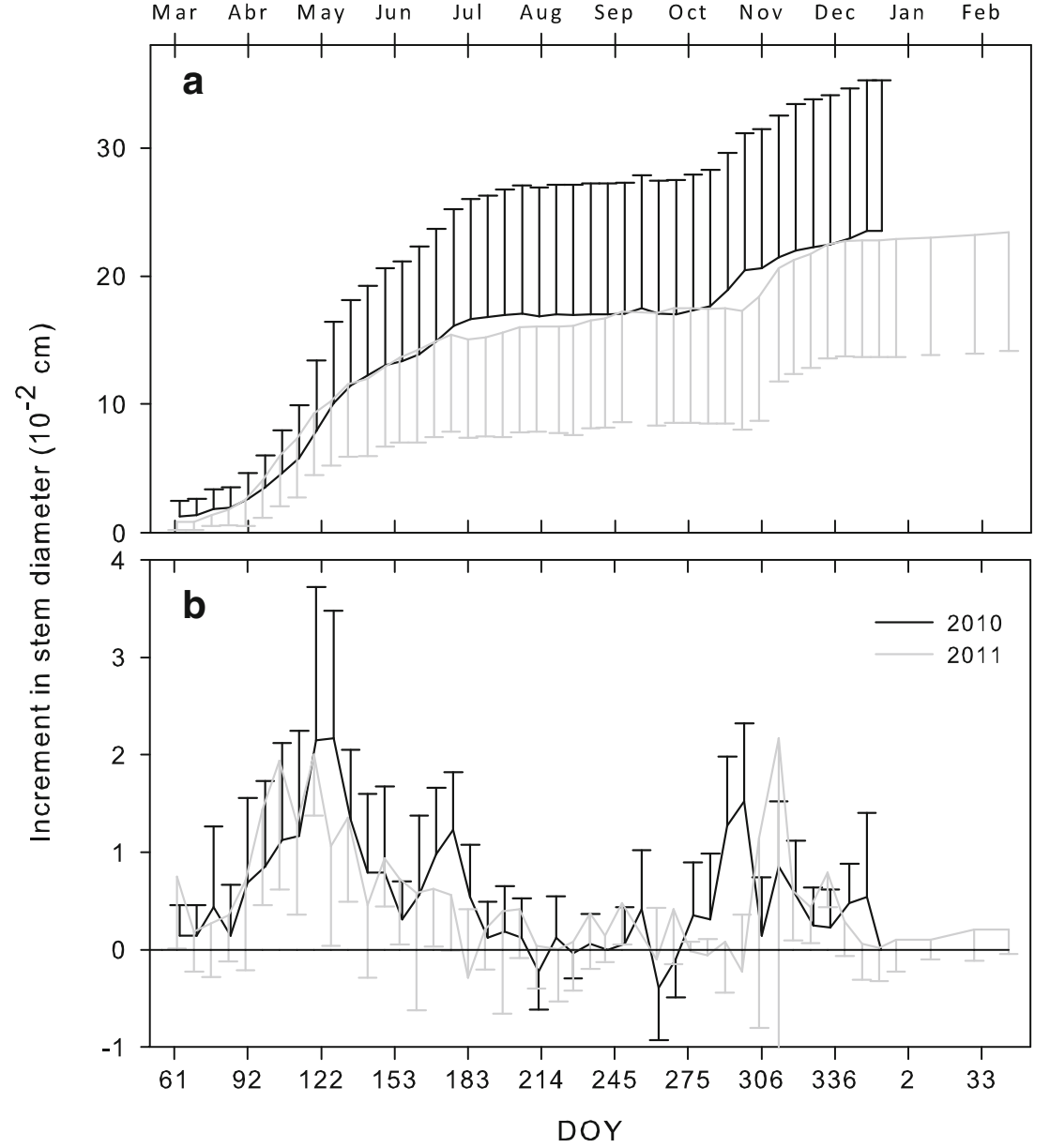

in the Mediterranean, cambium is also responsive to temperature. Dendrochronological studies in the Iberian Peninsula have shown a positive correlation between maritime pine tree-ring width and late winter temperature (Bogino and Bravo 2008; Campelo et al. 2013; Rozas et al. 2009). An earlier onset of cambial activity can correspond to a longer period of xylogenesis and thus wider tree rings (Lupi et al. 2010). However, we recognize that factors other than or in addition to temperature can also trigger the break of winter dormancy in trees, such as photoperiod (Rossi et al. 2006b; Nizinski and Saugier 1988).

\subsection{Impact of drought on xylem development}

Although cell differentiation started later, the tree ring formed in 2010 was wider than that of 2011. Thus, an earlier onset of cambial activity did not result in a larger tree ring or a longer duration of xylogenesis as reported by Lupi et al. (2010) in the boreal forest of Quebec. In fact, maritime pine wood formation appears to be more dependent on the rate of cell production than on the duration of xylogenesis (Vieira et al. in press). The maximum number of enlarging cells was observed between April-May in 2010 and in March in 2011.
Dendrochronological studies on maritime pine have shown that radial growth is closely related to April and May precipitation (Vieira et al. 2009; Campelo et al. 2013; Rozas et al. 2009; Bogino and Bravo 2008). During 2011, April and May precipitation were below average, especially May. In addition to lower spring precipitation, temperatures in April and May were $4.4{ }^{\circ} \mathrm{C}$ above the long-term mean. Thus, the spring period in 2011 was much drier when compared to 2010, as clearly shown by the more negative SPEI values. The warmer late winter and drier spring observed in 2011 displaced maximum cell production in time, from April-May to March, demonstrating that wood formation can adjust to the prevailing climate conditions. Oberhuber and Gruber (2010) reported the influence of water availability in tracheid production; they observed that enlargement stopped 2 3 weeks earlier in a xeric than in a mesic site in an inner Alpine valley. A similar negative effect of summer drought on tracheid production was also observed in the Mediterranean region, where tracheid formation in Aleppo pines decreased when precipitation was below a functional threshold (Pasho et al. 2012). Timings of xylogenesis appear to be controlled by climatic conditions, with no relation being observed between onset and end of xylogenesis. 
Water stress causes severe limitations to plant growth and metabolism, which leads to growth reduction and even tree mortality (Allen et al. 2010; Choat et al. 2012). During periods of drought, turgor-driven cell expansion, cell wall synthesis, and protein synthesis are substantially affected (Hsiao et al. 1976; Chaves et al. 2002). Trees respond to water stress by adopting one of two behaviors: isohydric or anisohydric (McDowell et al. 2008). Maritime pine adopts an isohydric behavior, which means that it will close its stomata in order to avoid hydraulic failure (Ripullone et al. 2007). By closing the stomata, carbon uptake and photosynthesis are affected, which translates into a decrease of carbohydrate availability, generally followed by a growth reduction (Michelot et al. 2012; Oribe et al. 2003) and ultimately carbon starvationinduced mortality (McDowell 2011; Adams et al. 2013). In an experimental study, using an isohydric species (Pinus edulis Engelm.), Adams et al. (2009) showed that warmer conditions $\left(\approx 4{ }^{\circ} \mathrm{C}\right)$ triggered a faster consumption of carbon reserves, increasing the risk of mortality due to carbon starvation. In 2010, xylem differentiation was still ongoing in mid-December with tracheids in the cell wall thickening phase still present. Average winter temperatures at the study site were around $10{ }^{\circ} \mathrm{C}$, which probably allowed tracheid differentiation to continue during winter. De Luis et al. (2007) made similar observations on Aleppo pines growing in Spain, suggesting that cell wall deposition is not limited by winter temperatures in the Mediterranean region.

\subsection{Tracheid characteristics}

The transition from early- to latewood reflects the availability of water for cambial activity (Domec and Gartner 2002). Although there was a higher number of latewood tracheids in 2010, latewood formation started earlier in 2011. Tracheid size is controlled by climatic conditions during the cell enlargement phase (Gricar et al. 2009; Olano et al. 2012). Low water content decreases cell turgor thus affecting cell enlargement resulting in smaller, denser, and mechanically stronger tracheids (Abe et al. 2003; Sperry et al. 2006). An increase of latewood width in Aleppo pines growing in Spain was observed by Pasho et al. (2012) in response to a pronounced decline in winter and spring precipitation. Besides the differences in the number of latewood tracheids, their anatomical characteristics also differed, with the 2011 latewood tracheids presenting smaller lumen areas. The formation of tracheids with smaller lumen area and thicker cell walls diminishes the hydraulic conductivity but increases the xylem resistance to drought-induced cavitation (DallaSalda et al. 2009; Hacke and Sperry 2001). Numerous studies have linked higher wood density in conifers with drought stress (Domec and Gartner 2002; Pittermann et al. 2006; Jyske et al. 2010). Belien et al. (2012) did a water exclusion experiment in the field and observed that the number of tracheids was unaffected by the treatment, but the lumen area of tracheids was reduced in trees subjected to rain exclusion. In the present study, a decrease was also observed in the lumen area of latewood tracheids in response to water stress, confirming that tracheid diameter is closely related to water availability, especially during drought periods (von Wilpert 1991).

\subsection{Diameter increment variations}

Our study revealed a close relationship between the rapid increment in stem diameter and the beginning of the enlargement phase in both years. Similar observations were made by Oberhuber and Gruber (2010) studying Pinus sylvestris stem radial variations in an Alpine valley. The diameter increment pattern of maritime pine showed two increments peaks, one in spring and another in autumn. This is in agreement with the growth pattern characteristic of the Mediterranean region, the bimodal increment pattern (Liphschitz and Levyadun 1986; Camarero et al. 2010). In spring, the onset of stem diameter increment occurred simultaneously in both years, although the maximum increment was observed two weeks earlier in 2011, corresponding to the differences observed in the enlargement phase. The second period of increment was observed in autumn. In both years, the xylem anatomy analysis revealed that after the summer drought, the cambium remained dormant, without cell division. The absence of a cellular division means that the second increment period was most likely due to rehydration of the stem. Increment in diameter consists of several components including the daily swelling and shrinking of the outermost tissues of the stem due to water absorption and thermal variations, and wood formation (Zweifel et al. 2006). Although the average stem diameter increment did not reveal a period of stem contraction during the summer, the analysis of the individual trees revealed a contraction period during summer. A study on the same site using automatic dendrometers showed a strong period of contraction during summer, followed by a rehydration period in autumn, confirming that the second increment period was mainly due to rehydration of the stem (Vieira et al. 2013).

\section{Conclusion}

In the Mediterranean area, maritime pine wood formation appeared to be under a double climatic control: onset of cambial activity was regulated by temperature, while growth cessation was triggered by low water availability. Although growth differentiation started earlier in 2011, it also ended earlier, demonstrating that timings and duration of xylogenesis were independent. Our results also demonstrated the influence of water availability on xylogenesis and tracheids features. 
Low water availability in April and May restricted cell production, which resulted in a smaller tree ring. Additionally, a longer drought period also had repercussions on tracheid anatomy with cells presenting a smaller lumen area. Band dendrometers recorded a bimodal pattern of stem radial increment; however, the anatomical analysis demonstrated that the second period of increment was mostly due to stem rehydration.

Acknowledgments The authors would like to thank A. Garside for checking the English. This study was supported by the Fundação para a Ciência e a Tecnologia, Ministério da Educação e Ciência (FCT) cofinanced by Compete, through the project PTDC/AAC-AMB/ $111675 / 2009$. Joana Vieira was supported by a $\mathrm{PhD}$ grant (SFRH/BD/ 48089/2008) and Filipe Campelo by a postdoctoral research grant (SFRH/BPD/47822/2008); both of them received grants from FCT with funds from Portuguese Operational Human Potential Program (POPH) and QREN Portugal (Portuguese National Strategic Reference Framework)

\section{References}

Abe H, Nakai T, Utsumi Y, Kagawa A (2003) Temporal water deficit and wood formation in Cryptomeria japonica. Tree Physiol 23:859-863

Adams HD, Germino MJ, Breshears DD, Barron-Gafford GA, GuardiolaClaramonte M, Zou CB, Huxman TE (2013) Nonstructural leaf carbohydrate dynamics of Pinus edulis during drought-induced tree mortality reveal role for carbon metabolism in mortality mechanism. New Phytol 197:1142-1151. doi:10.1111/nph.12102

Adams HD, Guardiola-Claramonte M, Barron-Gafford GA, Villegas JC, Breshears DD, Zou CB, Troch PA, Huxman TE (2009) Temperature sensitivity of drought-induced tree mortality portends increased regional die-off under global-change-type drought. Proc Natl Acad Sci U S A 106:7063-7066. doi:10.1073/pnas.0901438106

Allen CD, Macalady AK, Chenchouni H, Bachelet D, McDowell N, Vennetier M, Kitzberger T, Rigling A, Breshears DD, Hogg EH, Gonzalez P, Fensham R, Zhang Z, Castro J, Demidova N, Lim J-H, Allard G, Running SW, Semerci A, Cobb N (2010) A global overview of drought and heat-induced tree mortality reveals emerging climate change risks for forests. For Ecol Manag 259: 660-684. doi:10.1016/j.foreco.2009.09.001

Begum S, Nakaba S, Bayramzadeh V, Oribe Y, Kubo T, Funada R (2008) Temperature responses of cambial reactivation and xylem differentiation in hybrid poplar (Populus sieboldii $\times P$-grandidentata) under natural conditions. Tree Physiol 28:1813-1819

Begum S, Nakaba S, Oribe Y, Kubo T, Funada R (2007) Induction of cambial reactivation by localized heating in a deciduous hardwood hybrid poplar (Populus sieboldii $\times$ P. randidentata). Ann Bot 100: 439-447. doi:10.1093/Aob/Mcm130

Belien E, Rossi S, Morin H, Deslauriers A (2012) Xylogenesis in black spruce subjected to rain exclusion in the field. Can J For Res-Revue Canadienne De Recherche Forestiere 42:1306-1315. doi:10.1139/ x2012-095

Bogino SM, Bravo F (2008) Growth response of Pinus pinaster Ait. to climatic variables in central Spanish forests. Ann For Sci 65:506. doi:10.1051/forest:2008025

Camarero JJ, Olano JM, Parras A (2010) Plastic bimodal xylogenesis in conifers from continental Mediterranean climates. New Phytol 185: 471-480. doi:10.1111/j.1469-8137.2009.03073.x

Campelo F, Vieira J, Nabais C (2013) Tree-ring growth and intra-annual density fluctuations of Pinus pinaster responses to climate: does size matter? Trees - Struct Funct 27:763-772. doi:10.1007/s00468-0120831-3

Carrer M, Urbinati C (2006) Long-term change in the sensitivity of treering growth to climate forcing in Larix decidua. New Phytol 170: 861-871

Chaves MM, Pereira JS, Maroco J, Rodrigues ML, Ricardo CPP, Osorio ML, Carvalho I, Faria T, Pinheiro C (2002) How plants cope with water stress in the field. Photosynthesis and growth. Ann Bot 89: 907-916. doi:10.1093/aob/mcf105

Cherubini P, Gartner BL, Tognetti R, Braker OU, Schoch W, Innes JL (2003) Identification, measurement and interpretation of tree rings in woody species from Mediterranean climates. Biol Rev 78:119-148

Choat B, Jansen S, Brodribb TJ, Cochard H, Delzon S, Bhaskar R, Bucci SJ, Feild TS, Gleason SM, Hacke UG, Jacobsen AL, Lens F, Maherali H, Martinez-Vilalta J, Mayr S, Mencuccini M, Mitchell PJ, Nardini A, Pittermann J, Pratt RB, Sperry JS, Westoby M, Wright IJ, Zanne AE (2012) Global convergence in the vulnerability of forests to drought. Nature 491:752-755. doi:10.1038/nature11688

CRU, Netherlands Royal Meteorological Institute, 2011. CRU TS 3.1. http://climexp.knmi.nl/

Dalla-Salda G, Martinez-Meier A, Cochard H, Rozenberg P (2009) Variation of wood density and hydraulic properties of Douglas-fir (Pseudotsuga menziesii (Mirb.) Franco) clones related to a heat and drought wave in France. For Ecol Manag 257:182-189. doi:10. 1016/j.foreco.2008.08.019

de Luis M, Gricar J, Cufar K, Raventos J (2007) Seasonal dynamics of wood formation in Pinus halepensis from dry and semi-arid ecosystems in Spain. Iawa J 28:389-404

de Luis M, Novak K, Cufar K, Raventos J (2009) Size mediated climategrowth relationships in Pinus halepensis and Pinus pinea. Trees Struct Funct 23:1065-1073. doi:10.1007/s00468-009-0349-5

Denne MP (1989) Definition of latewood according to Mork (1928). Iawa Bull 10:59-62

Deslauriers A, Morin H (2005) Intra-annual tracheid production in balsam fir stems and the effect of meteorological variables. TreesStruct Funct 19:402-408

Deslauriers A, Rossi S, Anfodillo T, Saracino A (2008) Cambial phenology, wood formation and temperature thresholds in two contrasting years at high altitude in southern Italy. Tree Physiol 28:863-871

Domec JC, Gartner BL (2002) How do water transport and water storage differ in coniferous earlywood and latewood? J Exp Bot 53:2369 2379. doi:10.1093/jxb/erf100

Eilmann B, Zweifel R, Buchmann N, Pannatier EG, Rigling A (2011) Drought alters timing, quantity, and quality of wood formation in Scots pine. J Exp Bot 62:2763-2771. doi:10.1093/jxb/erq443

Ferreira O, Torrinha AM, Cardoso PM (2010) Plano de gestão florestal: Mata Nacional do Urso e Mata Nacional do Pedrogão

Fritts HC (1976) Tree rings and climate. Academic, London

Gricar J, Cufar K, Oven P, Schmitt U (2005) Differentiation of terminal latewood tracheids in silver fir during autumn. Ann Bot 95:959-965. doi:10.1093/aob/mci112

Gricar J, Krze L, Cufar K (2009) Number of cells in xylem, phloem and dormant cambium in silver fir (Abies alba), in trees of different vitality. Iawa J 30:121-133

Gricar J, Zupancic M, Cufar K, Koch G, Schmitt U, Oven P (2006) Effect of local heating and cooling on cambial activity and cell differentiation in the stem of Norway spruce (Picea abies). Ann Bot 97:943-951. doi:10.1093/aob/mc1050

Hacke UG, Sperry JS (2001) Functional and ecological xylem anatomy. Perspect Plant Ecol Evol Syst 4:97-115. doi:10.1078/1433-831900017

Hsiao TC, Acevedo E, Fereres E, Henderson DW (1976) Stress metabolism: water stress, growth and osmotic adjustment. Phil Trans R Soc London Series B Biol Sci 273:479-500. doi:10.1098/ rstb.1976.0026 
IPCC (2007) Climate change 2007: impacts, adaptation and vulnerability. Contribution of Working Group II to the Fourth Assessment Report of the Intergovernmental Panel on Climate Change. Cambridge Univertisy Press, Crambridge

Jyske T, Holtta T, Makinen H, Nojd P, Lumme I, Spiecker H (2010) The effect of artificially induced drought on radial increment and wood properties of Norway spruce. Tree Physiol 30:103-115. doi:10. 1093/treephys/tpp099

Korner C (1998) A re-assessment of high elevation treeline positions and their explanation. Oecologia 115:445-459. doi:10.1007/ s004420050540

Lebourgeois F, Merian P, Courdier F, Ladier J, Dreyfus P (2012) Instability of climate signal in tree-ring width in Mediterranean mountains: a multi-species analysis. Trees-Struct Funct 26:715729. doi:10.1007/s00468-011-0638-7

Linares JC, Camarero JJ, Carreira JA (2009) Plastic responses of Abies pinsapo xylogenesis to drought and competition. Tree Physiol 29: 1525-1536. doi:10.1093/treephys/tpp084

Linares JC, Camarero JJ, Carreira JA (2010) Competition modulates the adaptation capacity of forests to climatic stress: insights from recent growth decline and death in relict stands of the Mediterranean fir Abies pinsapo. J Ecol 98:592-603. doi:10.1111/j.1365-2745.2010. 01645.x

Liphschitz N, Levyadun S (1986) Cambial activity of evergreen and seasonal dimorphics around the Mediterranean. Iawa Bull 7:145153

Lupi C, Morin H, Deslauriers A, Rossi S (2010) Xylem phenology and wood production: resolving the chicken-or-egg dilemma. Plant Cell Environ 33:1721-1730. doi:10.1111/j.1365-3040.2010.02176.x

McDowell N, Pockman WT, Allen CD, Breshears DD, Cobb N, Kolb T, Plaut J, Sperry J, West A, Williams DG, Yepez EA (2008) Mechanisms of plant survival and mortality during drought: why do some plants survive while others succumb to drought? New Phytol 178:719-739. doi:10.1111/j.1469-8137.2008.02436.x

McDowell NG (2011) Mechanisms linking drought, hydraulics, carbon metabolism, and vegetation mortality. Plant Physiol 155:10511059. doi:10.1104/pp.110.170704

Michelot A, Simard S, Rathgeber C, Dufrene E, Damesin C (2012) Comparing the intra-annual wood formation of three European species (Fagus sylvatica, Quercus petraea and Pinus sylvestris) as related to leaf phenology and non-structural carbohydrate dynamics. Tree Physiol 32:1033-1045

Nizinski JJ, Saugier B (1988) A model of leaf budding and development for a mature Quercus forest. J Appl Ecol 25:643-652. doi:10.2307/ 2403851

Oberhuber W, Gruber A (2010) Climatic influences on intra-annual stem radial increment of Pinus sylvestris (L.) exposed to drought. Trees Struct Funct 24:887-898. doi:10.1007/s00468-010-0458-1

Olano JM, Eugenio M, Garcia-Cervigon AI, Folch M, Rozas V (2012) Quantitative tracheid anatomy reveals a complex environmental control of wood structure in continental Mediterranean climate. Int J Plant Sci 173:137-149. doi:10.1086/663165

Oribe Y, Funada R, Kubo T (2003) Relationships between cambial activity, cell differentiation and the localization of starch in storage tissues around the cambium in locally heated stems of Abies sachalinensis (Schmidt) Masters. Trees-Struct Funct 17:185-192. doi:10.1007/s00468-002-0231-1

Oribe Y, Funada R, Shibagaki M, Kubo T (2001) Cambial reactivation in locally heated stems of the evergreen conifer Abies sachalinensis (Schmidt) Masters. Planta 212:684-691
Pasho E, Julio Camarero J, Vicente-Serrano SM (2012) Climatic impacts and drought control of radial growth and seasonal wood formation in Pinus halepensis. Trees-Struct Funct 26:1875-1886. doi:10. 1007/s00468-012-0756-X

Pittermann J, Sperry JS, Wheeler JK, Hacke UG, Sikkema EH (2006) Mechanical reinforcement of tracheids compromises the hydraulic efficiency of conifer xylem. Plant Cell Environ 29:1618-1628. doi: 10.1111/1365-3040.2006.01539.x

Ripullone F, Guerrieri MR, Nole A, Magnani F, Borghetti M (2007) Stomatal conductance and leaf water potential responses to hydraulic conductance variation in Pinus pinaster seedlings. Trees-Struct Funct 21:371-378. doi:10.1007/s00468-007-0130-6

Rossi S, Anfodillo T, Menardi R (2006a) Trephor: a new tool for sampling microcores from tree stems. Iawa J 27:89-97

Rossi S, Deslauriers A, Anfodillo T, Carraro V (2007) Evidence of threshold temperatures for xylogenesis in conifers at high altitudes. Oecologia 152:1-12

Rossi S, Deslauriers A, Anfodillo T, Morin H, Saracino A, Motta R, Borghetti M (2006b) Conifers in cold environments synchronize maximum growth rate of tree-ring formation with day length. New Phytol 170:301-310

Rossi S, Deslauriers A, Gricar J, Seo JW, Rathgeber CBK, Anfodillo T, Morin H, Levanic T, Oven P, Jalkanen R (2008) Critical temperatures for xylogenesis in conifers of cold climates. Glob Ecol Biogeogr 17:696-707. doi:10.1111/j.1466-8238.2008.00417.x

Rozas V, Lamas S, Garcia-Gonzalez I (2009) Differential tree-growth responses to local and large-scale climatic variation in two Pinus and two Quercus species in northwest Spain. Ecoscience 16:299-310. doi:10.2980/16-3-3212

Sperry JS (2003) Evolution of water transport and xylem structure. Int J Plant Sci 164:S115-S127. doi:10.1086/368398

Sperry JS, Hacke UG, Pittermann J (2006) Size and function in conifer tracheids and angiosperm vessels. Am J Bot 93:1490-1500. doi:10. 3732/ajb.93.10.1490

Tyree MT, Zimmermann MH (2002) Xylem structure and the ascent of sap. Springer, Heidelberg

Vicente-Serrano SM, Begueria S, Lopez-Moreno JI (2010) A multiscalar drought index sensitive to global warming: the standardized precipitation evapotranspiration index. J Clim 23:1696-1718. doi: 10.1175/2009jcli2909.1

Vieira J, Campelo F, Nabais C (2009) Age-dependent responses of treering growth and intra-annual density fluctuations of Pinus pinaster to Mediterranean climate. Trees-Struct Funct 23:257-265. doi:10. 1007/s00468-008-0273-0

Vieira J, Campelo F, Nabais C (2010) Intra-annual density fluctuations of Pinus pinaster are a record of climatic changes in the western Mediterranean region. Can J For Res-Revue Canadienne De Recherche Forestiere 40:1567-1575. doi:10.1139/X10-096

Vieira J, Rossi S, Campelo F, Nabais C (2013) Are neighboring trees in tune? Wood formation study in Pinus pinaster. Eur J For Res. doi:10. 1007/s10342-013-0734-x

Vieira J, Rossi S, Campelo F, Freitas H, Nabais C (2013) Seasonal and daily cycles of stem radial variation of Pinus pinaster in a droughtprone environment. Agric For Meteorol 180:173-181. doi:10.1016/ j.agrformet.2013.06.009

von Wilpert K (1991) Intraanual variation of radial tracheid diameters as monitor of site specific water stress. Dendrochronologia 9:95-113

Zweifel R, Zimmermann L, Zeugin F, Newbery DM (2006) Intra-annual radial growth and water relations of trees: implications towards a growth mechanism. J Exp Bot 57:1445-1459. doi:10.1093/jxb/erj125 